\title{
LIFE STRATEGIES OF SENIOR STUDENTS AS THE ABILITY TO DETERMINE LIFE PURPOSES IN MODERN CIRCUMSTANCES
}

\author{
MARINA MARCHENOKA \\ Faculty of Education, Language and Design, Rezekne Academy of \\ Technologies \\ Atbrivosanas aleja 115, Rezekne, LV-4601, Latvia \\ E-mail: marina-mar4enoka@inbox.lv \\ ORCID: https://orcid.org/0000-0002-0922-636X
}

\begin{abstract}
Aim. The purpose of this article is to define the scientific paradigm in understanding of the concept of "life strategies of a person" and to conduct an empirical research in order to determine average values of indicators of life meaningfulness and subjective perception of the past, present, and future of senior students in Latvia.

Methods. The research is based on the theoretical study of different conceptual approaches to comprehension of the phenomenon life strategies. Following research methods were used: 1) Dmitry Leontiev's test defined in "purpose life orientations" method (2006) for data acquisition; 2) a method "past, present and future" by Svetlana Mezhvidova (2001); 3) "colour test" method invented by Max Lüscher (1990). For processing data following analysis methods were used: processing of quantitative data by applying methods of mathematical analysis of statistical data as well as forecasting analytical methods; Student's t-test to compare medians of two independent samples; Spearman's rank correlation; processing of qualitative data: content study and analysis, coding and processing of the obtained data; elucidation of quantitative and qualitative analysis.

Results and conclusions. The theoretical analysis suggests that there is a definite scientific paradigm in understanding of the concept of life strategies of senior students. The empirical research showed that Latvian senior students have the average indicators of sense life orientations and that they are quite low according to statistically different scales. It characterises the insufficient process of setting and defining goals by senior students, the achievement of which would help them acquire the sense of meaningfulness, direction, and hopefulness of future life.
\end{abstract}

Key words: senior students, life strategies, purpose life orientations, perception of the past, perception of the present, perception of the future, society

\section{INTRODUCTION}

$\mathrm{T}_{\mathrm{s}}$ he current stage of development of the European society is characterised by global processes of transformation in all spheres of life. The deep crisis in 
the economy, growing social instability, frightening COVID-19 pandemic and its consequences, serious crisis of values - all of the above-mentioned factors have a negative impact not only on the society as a whole, but also on the younger generation in particular, thus complicating and destabilising the ability to plan and build the future life course of a modern person.

Under these conditions, the research of life strategies and meaningfulness of an individual's life becomes particularly relevant, which is determined by a number of reasons. First, the young generation is one of the main subjects while talking about the society's development, and the study of its life strategies becomes an important indicator that helps to anticipate future processes and trends in development of the society as a whole. Secondly, the modern society is actively moving away from the development of collective, common thinking, offering senior students an individual choice of their life plans based on their values, needs, interests, goals and priorities. It is in the older age of adolescence when the worldview is built as a stable system of beliefs, ideals and norms of behaviour acquired in the process of socialisation, which determines the life activity of an individual throughout the rest of his or her life.

The research aim is to define the scientific paradigm in understanding of the concept of "life strategies of a person" and conducting an empirical research in order to determine average values of indicators of life meaningfulness and subjective perception of the past, present and future of senior students in Latvia.

\section{THEORETICAL FRAMEWORK}

The modern world is the world of formation, development and realisation of various vital human strategies. The young generation occupies a special place in the society, since their worldview, value orientations, needs, interests, as well as aims and priorities define the future of any country and the world as a whole.

The concept of "life strategies" as a key concept is investigated in the spheres of philosophy, social psychology, sociology and pedagogy and is related to the definition of the future, which can be considered on the macro and micro level. The macro level represents scientific works regarding investigation of the future of large-scale structures and processes: the future of the planet, state, society. The micro level includes studies investigating the personality as an active subject of the process of individual's life activity. Studies conducted on macro level are, for example, Frank Webster's Theories of the information society (2014), Alvin Toffler's Future shock (2019), Zygmunt Bauman's The individualised society (2001), Ulrich Beck's Risk society (2000), Jean Baudrillard's The consumer society (1998), Daniel Bell's The coming of post-industrial society: A venture of social forecasting (2007), etc. The micro level studies include works such as Lyubov Osipova and Liliya Enveri's Life strategies of young people: Sociological research experience (2016), Kseniya Abuljkhanova-Slavskaya's Life strategy (1991), Karen Horney's Self-analysis (2009), Alfred Adler's Practice and theory of individual psychology (2011), Edward L. Deci and 
Richard M. Ryan's The 'what' and 'why' of goal pursuits: Human needs and the self-determination of behaviour (2009), etc.

Since the given investigation aims at definition of senior students' goals and life perspectives, it means that the theoretical justification must contain the analysis of the concepts and theories of those authors who consider the personality as a subject of the process of individual vital activity in the modern society, that is from the point of view of the micro level.

Thus, Enveri and Osipova (2016) consider the life strategies as "a dynamic system, which is characterised by the distinctly built system of value orientations, associated aims and comprehension of behavioural sets" (p. 110). The determination of the life path of a young person, in their opinion, is "a purposeful process of realisation of the life conception, and its success depends on the person's social activity and ability to accept responsibility" (p. 110).

Abuljkhanova-Slavskaya (1991) implemented a complex analysis of the life strategy of a person defining the concept of "life strategy," as well as the essence and main characteristics of life strategies and factors which influence their development and realisation. She also suggested the typology of strategies. In her analysis, she affirms that the life strategy is "an essential ability of a person to adjust his or her individuality to the living conditions, which is realised in different life conditions and circumstances" (p. 127). The author distinguishes three fundamental features of the life strategy:

- the choice of the main direction, the way of life, the definition of its main goals and the stages of their achievement;

- achieving life goals and plans, finding a solution for the contradiction "I want - I have";

- creating conditions for self-realisation and creative endeavour.

In Abuljkhanova-Slavskaya's opinion, a person can be called mature only if he or she is able to "set his or her own limit of satisfaction with material needs and starts to consider them as one of the conditions of life, directing the life forces to other goals" (1991, p. 119). She attributed the activity of an individual to the main parameter of building the life strategy. In her opinion, it appears as "the ability to balance between the desired and the necessary, the personal and the social" (p. 128).

Horney (2009) had her own approach to life strategies. She investigated personal strategic orientations in the system of relationships "I - the other people" as a movement. She noted that in order to meet social patterns and own aspirations, each person develops three main strategies or personal orientations in relation to other people from childhood:

- moving towards people: love is the only goal for people belonging to this orientation, and all other goals are subordinated to the desire to merit this love;

- movement against people: the value system of people of this orientation is based on the "jungle" philosophy, i.e., the struggle for existence is life;

- movement from people: the need for independence and privacy turns such people away from any manifestation of struggle. It is often expressed only in the absence of an adequate way to adapt to the modern living conditions. (p. 84) 
Adler (2011), on the other hand, considered life strategies using an adaptive approach. He believed that during childhood, a person's life goals are developed as "an integrated style of adaptation to life and interaction with it" (p. 98). It defines the principal life goals or strategies that a person faces and which are determined by the conditions of human existence - love, friendship and work. In his opinion, they allow the individual to adapt to the environment around him or her in the most optimal way. "Each person chooses a life goal, reflecting his or her aspirations and priorities, each person is the arbiter of his destiny, it is him or her, who develops the life goal, which determines aspirations and achievements" (p. 115).

The issue of life aspirations and basic needs is most productively developed in the theory of self-determination developed by Deci and Ryan (2009), defining the concepts of life aspirations and basic needs, and offering methods for their diagnostics. According to Deci and Ryan, self-determination (or autonomy) is defined as "the feeling and realisation of a person's freedom to choose a way of behaviour and existence in the world, regardless of the external environment and intrapersonal processes affecting him or her" (p. 229). On the basis of identification of two types of motivation (external and internal) the authors identified two corresponding groups of life aspirations. They attributed personal growth, health, desire for love and affection, as well as service to the society to the internal aspirations, defining the given group as life goals, accomplishing of which provides satisfaction of basic psychological needs, as well as promotes personal growth and mental health. The second group of aspirations (external) includes material well-being, social recognition through popularity (fame), and physical attractiveness (appearance). The authors emphasise that the choice of the life strategy also depends on the role of parents while upbringing a child.

The individualistic approach to the study of life strategies belongs to Carl Gustav Jung (2020). He believed that people continuously acquire different new skills, achieve new goals, and reveal themselves more and more throughout their life. Jung considered the most important life goal of a person to be "finding and manifesting oneself" (p. 336). In Jung's opinion, the full disclosure of the "I" is the most important goal of a person's life, i.e., the formation of a single, unique and integral individual. "The development of each person in this direction is unique, it goes on throughout life and includes a process, which was named 'individualisation'" (p. 341).

Thus, the theoretical study and analysis gave the possibility to define that there is an explicit scientific paradigm in comprehension and understanding of the concept of "life strategies of person." Within the scope of the paradigm, the life strategy is considered as a person's ability to make an individual choice of a system of life strategies based on the aims and ways of goal achievement, deriving from worldviews and values, needs and interests, priorities and responsibility of the person, as well as from the ability of the person to balance between the desired and the necessary, the personal and the social. 


\section{EMPIRICAL RESEARCH}

The empirical research for this article had the following aims:

- to define average values of indicators of life meaningfulness (life purpose, process of life, results, self-locus control, locus of control life) among senior students in Latvia;

- to determine the subjective understanding of the senior students' past, present and future and to characterise the emotional condition of senior students in Latvia.

Students of the $11^{\text {th }}$ and $12^{\text {th }}$ forms of different institutions of general education in Latvia were the respondents of the empirical research presented below (Table 1). The testing was conducted from September until November 2020.

Table 1

Base of the empirical research

\begin{tabular}{ccccc}
\hline & Frequency & Percent & Valid percent & $\begin{array}{c}\text { Cumulative } \\
\text { percent }\end{array}$ \\
\hline Valid & & & & \\
$11^{\text {th }}$ grade & 107 & 52.8 & 52.8 & 52.8 \\
$12^{\text {th }}$ grade & 95 & 47.2 & 47.2 & 47.2 \\
\hline Total & 202 & 100.0 & 100.0 & 100.0 \\
\hline
\end{tabular}

Source: own research.

\section{RESEARCH METHODS}

Methods of obtaining the necessary data:

- Leontiev's test "purpose life orientations" based on Muzdibayev's version (adapted model of Crumbaugh and Maholick's test "purpose in life"); anonymous, the respondents only indicated their age (Crumbaugh \& Maholick, 1964; Leontiev, 2006);

- Mezhvidova's method "past, present and future" (based on the "the self-social symbols tasks" - principles of the projective technique of investigation of the personality) applying Lüscher's "colour test" (anonymous, the respondents only indicated their age) (Lüscher, 1990; Mezhvidova, 2001).

Methods of processing and analysing of the obtained data:

- quantitative or numerical data processing, applying methods of mathematical analysis of statistical data, forecast analytical methods using data processing software SPSS Statistics V22.0 (Statistical Package for the Social Sciences);

- T-test to compare medians of two independent samples (student test);

- Spearman rank correlation;

- qualitative data processing, including content analysis and coding and processing of the obtained data);

- interpretation of elucidation of quantitative and qualitative analysis. 
The "purpose life orientations" test included 20 pairs of opposite statements; every statement is an affirmation with a bisected end: two opposite options define two opposite ends of the evaluation scale; there are seven levels of gradation. The participants of the research were offered to choose the statements that fit them the most and to evaluate them by a definite number of seven gradations. When processing the results, the quantitative value of all the 20 scales was summed and converted into the standard value (\%). The defined factor structure of the questionnaire includes five scales:

Life purpose. The scale exhibits whether the respondent has or does not have a future goal, which gives direction, time perspective and sense to one's life (points $3,4,10,16,17,18$ of the test).

Life process or emotional saturation. The scale defines the satisfaction with one's life at the moment (in the present) and shows the perception of the life course as interesting, emotionally saturated and full of sense (points 1, 2, 4, 5, 7,9 of the test). The content of this scale corresponds to the notion that the only sense of life is just living.

Effectiveness of life, satisfaction with self-actualisation. The scale measures the satisfaction with the period of life which has been lived, the assessment of the past experience, the sensation of the level of productivity and the sense of the experience (points 8, 9, 10, 12, 20 of the test).

Self-locus control. The scale characterises the conception about oneself as a strong personality, having sufficient freedom of choice to build one's life according to one's aims and conceptions about its sense and to control events of one's life (points 1, 15, 16, 9 of the test).

Locus of control or life controllability. The scale reflects the confidence in the fact that every person in the world is given the right to control his or her life, to make decisions and fulfil them, as well as the assurance that a man's life is within the conscious control of every person (points 7, 10, 11, 14, 18, 19 of the test).

The "past, present and future" method is based on the principles of the projective methodology of investigation of a person's "self-social symbols task," representing the notions of the past, present and future in various amounts (Table 2). The respondents are offered to select the amount in the time period corresponding to their subjective sense of the past, present and future. The respondents executed a graphical test (a circle test), which determined the significance of a particular time period of their lives: past, present and future, as the perception and experience of relations between the main events in their lives. Their task was to represent their past, present and future in a form of three circles. They chose the size of circles themselves. When analysing results of the test, not only the size of the circles was taken into account, but also the distance between them (the spatial time model).

The respondents' choice was studied and analysed in line with the relative preference of past, present or future. The preference means the respondent's choice of the largest amount in the given period of time in comparison with other periods. 
Table 2

Method "past, present and future" by S. Mezhoidova

\begin{tabular}{|c|c|c|c|}
\cline { 1 - 1 } Past & \multirow{2}{*}{} & \\
\cline { 1 - 1 } Present & & & \\
\cline { 1 - 3 } Future & Large amount of time & $\begin{array}{c}\text { Moderate amount of } \\
\text { time }\end{array}$ & Short amount of time \\
\hline
\end{tabular}

Source: own research.

For the correlation analysis (Spearman rank correlation) Lüscher's (1990) method of presentation of the range of subjective colour preference was used. Taking into account the fact that a person chooses a colour unintentionally, it indicates the person's real characteristics, but not in the way of how the person sees himself or herself or what he or she wants to be. It may be seen in the analysis of questionnaires very often. Lüscher's test is based on the assumption that the choice of colour reflects the focus of the respondent on a certain emotional state, activity, or mood. Lüscher believed that colour perception is universal, but colour preferences are individual. Based on this belief, knowing the colours which a person prefers, understanding their meaning, it is possible to draw conclusions about the properties of his or her character and inner state, about his or her aspirations and needs.

\section{RESULTS}

The data obtained with the help of the test of purpose life orientations are shown in Table 3, which contains average values of indicators of life comprehension according to all the five scales ( 1 - life purpose, 2 - process of life, 3 - results, 4 - self-locus control, 5 - locus of control).

Table 3

Average values of "purpose life orientations" test of the students of $11^{\text {th }}-12^{\text {th }}$ forms

\begin{tabular}{lcccc}
\hline \multicolumn{1}{c}{ "Purpose life } & $\begin{array}{c}\text { Students of the } \\
11^{\text {th }} \text { form average } \\
\text { value (\%) }\end{array}$ & $\begin{array}{c}\text { Students of the } \\
12^{\text {th }} \text { form average } \\
\text { value }(\%)\end{array}$ & $\begin{array}{c}\text { T-criterion } \\
\text { of the } \\
\text { students }\end{array}$ & $p$ \\
\hline $\begin{array}{l}\text { Life purpose } \\
\text { Life process or emotional } \\
\text { saturation }\end{array}$ & 24.6 & 23.5 & 2.77 & 0.001 \\
$\begin{array}{l}\text { The effectiveness of life, } \\
\begin{array}{l}\text { Satisfaction with self- } \\
\text { actualisation }\end{array}\end{array}$ & 26.5 & 27.7 & 1.76 & 0.1 \\
$\begin{array}{l}\text { Self-locus control } \\
\begin{array}{l}\text { Locus of control or life } \\
\text { controllability }\end{array}\end{array}$ & 22.5 & 30.8 & 3.49 & 0.05 \\
\hline
\end{tabular}

Source: own research. 
The first 3 factors form purpose life orientations:

Life purpose (the future). The scale showed rather low values, thus characterising the insufficient process of setting and defining goals among senior students, the achievement of which would help them acquire the sense of meaningfulness, directivity and perceptiveness of life. Most likely, it is related to the raging COVID-19 pandemic, since many respondents stated dissatisfaction with the educational process (the remote studying process) and knowledge, which is necessary for admission to a university; ambiguity, uncertainty in choosing a future profession and in general further life goals (the key phrase of the respondents was "I have got no goals, I live the life as it is").

Life process or emotional saturation (the present). The indicators of the given scale indicate that, in general, senior students find their life interesting, but emotionally and meaningfully unsaturated, which can also be associated with the COVID-19 pandemic (the key phrases of the respondents are "I'm tired of long-term restrictions; I can't attend any sport or entertainment events; I can't freely meet my friends," etc.).

Effectiveness of life, satisfaction with self-actualisation (the past). The indicators of this scale show that if you need to sum up the period of life that has already passed, this period of life will be positive (the key phrases of the respondents are "I dreamt to become a doctor, so I learnt a lot, attended additional lessons"; "I travelled a lot and learnt about the world"; "I worked part-time in summer," etc.).

Two latter factors characterise and describe the internal locus of control as a general vision about the fact that the control is possible, as well as the person's own capabilities and ability to exercise the control.

Self-locus control. The factor indicates that during the given period of time, senior students are not able to construct their life according to their goals and ideas about its sense and meaning, to balance between the desirable and the possible (the key phrases of the respondents are "the inability to study and work abroad"; "start up their own business"; "travel" etc.).

Locus of control or life controllability. The factor indicates that senior students are not confident of the control possibilities during this period, and of the possibility to make their life choices independently (the key phrases of the respondents are: "our life does not depend on conscious control"; "freedom of choice is illusory and at the moment it makes no sense to plan ahead," etc.).

Table 4

Preference of "Past," "Present" or "Future" in the $11^{\text {th }}-12^{\text {th }}$ forms

\begin{tabular}{cccc}
\hline & $\begin{array}{c}\text { Large amount of time } \\
11^{\text {th }}-12^{\text {th }} \text { forms (1) }\end{array}$ & $\begin{array}{c}\text { Moderate amount of } \\
\text { time } 11^{\text {th }}-12^{\text {th }} \text { forms }(2)\end{array}$ & $\begin{array}{c}\text { Short amount of time } \\
11^{\text {th }}-12^{\text {th }} \text { forms (3) }\end{array}$ \\
\hline Past & $62.8 \%$ & $26.8 \%$ & $10.4 \%$ \\
Present & $38.5 \%$ & $53.9 \%$ & $7.6 \%$ \\
Future & $36 \%$ & $34 \%$ & $30 \%$ \\
\hline
\end{tabular}

Source: own research. 
As it can be seen in the Table 4, the past is widely presented, the present - in the moderate amount, but the future is distributed evenly between the three amounts.

Consequently, the layout in the selection of respondents who are oriented towards past (past -1 , present -2 , future -2 ) is presented as follows: $+3+2$ * 1 * $5=4=6-7-0$.

The past is presented in large amount. The explanation of the colour rank is the following: for the respondents who are oriented towards the past, the red colour is in the first position. The colour, which was chosen by a respondent in the first position, indicates the main way of action, that is, a tool for goal achievement. These participants of the research persistently pursue their aims and goals and do not allow themselves any deviation from the chosen way. They are willing to overcome all difficulties that they face in their life and to gain other people's particular recognition and respect at the cost of their achievements. They can be characterised by the adequacy of claims and the ability to assess their possibilities in a definite situation. These are people who believe that they are responsible for everything that is happening with them in their lives. Dominance of the red colour symbolises the need for achievement, leadership, purposefulness and high search activity, but all these characteristics are related to the past, which shows that a larger part of the respondents are oriented towards it.

The layout of colours in the selection of respondents who are oriented to the future (future -1 , present -2 , past -3 ) is presented as follows: $+6+4$ * 1 * 2 $=5=0-7-6$.

The future is distributed evenly between the three amounts. The results of the analysis display that future does not play a key role in the students' life. The largest part of the respondents cannot even single the future out and perceive it independently. They perceive it separately from the past or present. Dominance of the brown colour indicates that these are teenagers who have a need for emotional involvement and social security. Brightness of experiences and communication for obtaining experience is a necessary process for them. Nevertheless, they believe that the external circumstances and conditions are also in charge for everything that is happening around them. However, the yellow colour in the last position indicates the destruction of hopes, which depresses the individual.

The layout of colours in the selection of the respondents who are oriented to the present (present- 1 , future- 2,3 , past- 2,3 ) is presented as follows: $+4+7$ * 4 * $5=1=7-6-0$.

The present is exhibited in a medium amount. The colour rank can be interpreted in the following way: the given students are searching for success, they need recognition, they are ambitious, they want to impress others, they look for a way out of various situations, but they are characterised by pessimistic attitude, disappointment and pronounced emotional tension. Desire to escape from problems and responsibilities encounters a serious obstacle causing a sense of protest. Spontaneity of actions and statements can outstrip 
the forethought. Also, in this research, the distance and location of the circles in relation to each other was important. The closer circles are drawn to each other, the stronger and the more significant is the relationship between the time periods. And vice versa, when they are farther away from each other, there is also less dependence and connection of the times (past, present or future). What is more, the research showed that the distance of the circles between the present and the past is quite close, which suggests the significance and relationship between these times, but the future is separated from the present and the past.

\section{RESULTS AND CONCLUSIONS}

The theoretical study and analysis gave the possibility to define that there is an explicit scientific paradigm in the comprehension and understanding of the concept of "life strategies of a person." Within the scope of the paradigm, the life strategy is considered to be a person's ability to make an individual choice of a system of life strategies. It may be based on the aims and ways of goal achievement, deriving from worldviews and values, needs and interests, priorities and responsibility of a person, as well as from the ability of a person to balance between the desired and the necessary, the personal and the social.

The data which were obtained with the help of purpose life orientations test, give the possibility to conclude that the average indicators are quite low according to statistically different scales. It characterises the insufficient process of setting and defining goals by senior students, the achievement of which would help them acquire sense of meaningfulness, direction and understand hopefulness of future life. It indicates that:

- in general, senior students find their life interesting, but emotionally and meaningfully unsaturated;

- senior students fail to build their lives according to their goals and ideas about its meaning, they do not manage to balance between the desired and the possible;

- senior students experience lack of confidence in the fact that control is possible at the given period, and in the possibility of independent implementation of life choices, which they have made. They believe that freedom of choice is illusory and there is no point in planning ahead.

The method "past, present and future" demonstrated that senior students, who will start living their independent life in the nearest future, are living in the present, their life is affected by yesterday, and their personal feelings and subjective perceptions are explicitly referred or directed to the past experience (with high sensitivity to the past), and not to the future. 


\section{REFERENCES}

[1] Abuljkhanova-Slavskaya, K. (1991). Strategii zhizni [Life strategies]. Moscow: Mislj.

[2] Adler, A. (2011). Praktika i teorija individualjnoj psihologiji [Practice and theory of individual psychology]. Moscow: Akademicheskij project.

[3] Bauman, Z. (2001). The individualised society. Cambridge, United Kingdom: Polity Press.

[4] Beck, U. (2000). Obschestvo riska [Risk society]. Moscow: Progress-Tradicija.

[5] Bell, D. (2007). The coming of post-industrial society: A venture of social forecasting. United Kingdom: World of Books.

[6] Baudrillard, J. (1998). The consumer society. Paris: Gallimard.

[7] Crumbaugh, J. \& Maholick, L. (1964). An experimental study in existentialism: The psychometric approach to Frankl's concept of noogenic neurosis. Journal of Clinical Psychology, 20(2), $4-81$.

[8] Deci, E. \& Ryan, R. (2009). The "what" and "why" of goal pursuits: Human needs and the self-determination of behaviour. Journal of Psychological Inquiry, 11(4), 227-268.

[9] Horney, K. (2009). Samoanaliz [Self-analysis]. Moscow: Akademicheskij project.

[10] Jung, C. G. (2020). Ocherki po analiticheskoj psihologiji [Essays on analytical psychology]. Kiev: Harvest.

[11] Leontiev, D. (2006). Test smislozhiznennih orientacij [Life-meaning orientation test]. Moscow: Smisl.

[12] Lüscher, M. (1990). Luscher color test. New York: Pocket.

[13] Mezhvidova, S. (2001). Psihologicheskie tipi. Tipoligija 69 [Psychological types. Typology 69]. Moscow: Ast-Press.

[14] Osipova, L., \& Enveri, L. (2016). Life strategies of young people: Sociological research experience. Journal of Economic and Social Changes: Facts, Trends, Forecast, 4(46), 108-129.

[15] Toffler, A. (2019). The complete future shocks. Oxford, United Kingdom: Rebellion.

[16] Webster, F. (2014). Theories of the information society. London: Routledge. 


\title{
FORMATION OF SUSTAINABLE DEVELOPMENT COMPETENCIES IN PRIMARY SCHOOL CHILDREN
}

\author{
HANNA CHAIKOVSKA
}

Department of Pedagogy and Methods of Primary and Preschool Education

Faculty of Pedagogy and Psychology

Ternopil Volodymyr Hnatiuk National Pedagogical University

vul. Kryvonosa 2, Ternopil, 46027 Ukraine

E-mail address: chaicov78@tnpu.edu.ua

ORCID: https://orcid.org/0000-0003-4614-3843

\section{OLEKSANDRA YANKOVYCH}

Faculty of Social Sciences, Law and Humanities

Kujawy and Pomorze University in Bydgoszcz

ul. Toruńska 55-57, 85-023 Bydgoszcz, Poland

E-mail address: yankov@tnpu.edu.ua

ORCID: https://orcid.org/0000-0003-4253-5954

\section{IRYNA LEVCHYK}

Foreign Languages Department

Faculty of Foreign Languages

Ternopil Volodymyr Hnatiuk National Pedagogical University

vul. Kryvonosa 2,Ternopil, 46027 Ukraine

E-mail address: iralevchyk@tnpu.edu.ua

ORCID: https://orcid.org/0000-0003-2428-4928

\section{IRYNA KUZMA}

Department of Pedagogy, Psychology and Inclusive Education

Ternopil Regional Municipal Institute of Postgraduate Pedagogical Education vul. Hromnytskoho 1, Ternopil, 46027 Ukraine

E-mail address: iryna.ihorivna.kuzma@gmail.com

ORCID: https://orcid.org/0000-0002-1219-8216

\section{TETIANA ROZHKO-PAVLYSHYN}

Department of Pedagogy and Methods of Primary and Preschool Education

Faculty of Pedagogy and Psychology

Ternopil Volodymyr Hnatiuk National Pedagogical University vul. Kryvonosa 2, Ternopil, 46027 Ukraine

E-mail address: t.rozhko-pavlyshyn@tnpu.edu.ua

ORCID: https://orcid.org/0000-0003-2781-5982 


\section{ABSTRACT}

Aim. The article provides a new solution to the problem of the formation of sustainable development competencies in primary school students. The objective of the article is to substantiate the method of forming sustainable development competencies in primary school students and to reflect it in the model.

Methods. The main research methods are observation, test, interview, questionnaire, analysis of media works, expert evaluation, and pedagogical experiment. A set of diagnostic tools has been specified.

Results and conclusions. The efficiency of the developed technique has been proved with the results obtained from the experiment: the partnership of teachers, students and parents contributes to sustainability competencies formation; implementation of common areas of media education and education for sustainable development evidenced to feasibility of the research, namely: education in legal, economic aspects, creation of media products with a projection to sustainable development, learning critical perception of mass media information, sustainability goals orientation. Due to the introduction of the experimental methodology, the number of students with high $(12.07 \%)$ and satisfactory $(14.65 \%)$ levels of the key competencies in the field of sustainable development increased against the background of a decrease in the number of respondents with sufficient (12.93\%) and low (13.79\%) levels.

Originality. Emphasis is placed on the features of the designed methodology: application of partnership pedagogy and pedagogy of empowerment, integration of education for sustainable development with media education, compliance with a number of pedagogical conditions, forms and methods.

Key words: education for sustainable development, competences, methods of competencies formation, primary education

\section{INTRODUCTION}

Towadays humanity is facing many problems, such as global warming, 1 environmental pollution, poverty, scarcity of natural resources and others, which are caused mainly by the consequences of its activity and lifestyle. All these problems can be resolved by means of the sustainable development of society. The goals of sustainable development are supported by the United Nations Organisation, which identified three main dimensions of activity (economic, social and environmental), reflected in 17 global goals, including quality education (UNESCO, 2021). The foundation of a new educational space on the basis of sustainable development is its initial stage in the process of formation of a school graduate's personality.

In this study, formation of sustainable development competencies is interpreted as a form of educational activity aimed at implementing the ideas, principles and values of sustainable development in the educational process of primary school in order to form the key competencies for sustainable development in junior pupils. 


\section{LITERATURE REVIEW}

The formation of global competencies draws a lot of attention and is often present in the scientific and pedagogical discourse around the world. Over the past three decades there have been synthesised a set of so-called "key competencies in the field of sustainable development" according to Arnim Wiek, Lauren Withycombe, and Charles Redman (2011). As it is argued by Ellen Carm (2013), this is an important process because the choice of key competencies should result in the change of educational programmes, forms and methods of teaching, methodological and theoretical approaches, pedagogy, and educational environment in general.

In the works of scientists, significant attention is paid to the problems of sustainable development competencies in junior students. These problems have been studied by Aaron Benavot (2014), Mike Summers and Colin Kruger (2003), Ewa Szadzińska (2017), Hedviga Tkáčová, Martina Pavlíková, Miroslav Tvrdoň and Zita Jenisová (2021) and others. In particular, Summers and Kruger (2003) believe that the education of primary school students in sustainable development depends on the teacher's awareness in this area. Therefore, it has been recommended to integrate the ideas of sustainable development into the content of educational programmes for the retraining of primary school teachers, because they are the agents of change.

It must be noted that primary school curriculums contributing to sustainable development are expected to have a transdisciplinary character (Munkebye et al., 2020; Vásquez, García-Alonso, Seckel, \& Alsina, 2021).

Benavot (2014) emphasises that the issues of sustainable development in primary school focus primarily on the environmental component and that they are based on previous programmes in environmental education. However, education for sustainable development has a broader meaning.

The principles of education for sustainable development have been an object of scientific interest of Arthur da Silva et al. (2020), who developed the practical aspects of their implementation.

Szadzińska (2017) proposes to make changes in the goals, content, and methods of education to form students' sustainability competencies. However, in her works, we do not find either methodology or detailed descriptions of methods of forming these competencies.

The use of media methods in the Slovak school environment in order to raise awareness of sustainable development has been highlighted by Tkáčová et al. (2021). Application of various forms of media education in the context of sustainable development expands regular educational and upbringing school functions to informative, ethical and moral, awareness function, motivational and, preventive ones. The researchers consider the concept of sustainable development to be an issue of human individual responsibility that results in the introduction of collective participation and collective responsibility on sustainability in a school environment that is achieved by means of the traditional and new media. 
Analysis of the works of scientists and the empirical research designed by the authors of this paper outline the purpose of the article: to substantiate the method of forming the competencies of sustainable development in primary school students and to reflect it in the model.

\section{RESEARCH METHODS}

The following methods have been used to fulfil the purpose and tasks of scientific research: supervision, test, questionnaire, the analysis of products of media education, and pedagogical experiment which provided an expert assessment on the definition of levels of formation of the sustainable development competencies.

\section{Participants}

The experiment involved 228 fourth-grade students representing both urban and rural schools (secondary schools of I-III grades no. 4 and 16 Ternopil; secondary schools of I-III in villages Ozerna and Skalat, Ternopil region). The experimental study was conducted in the academic years 2019/2020 and 2020/2021. Participants were divided into control and experimental groups.

\section{Tools and materials}

Experimental learning resources consisted of: 1) lessons of the integrated course "I Explore the World" including the content for sustainable development and education for sustainable development; 2) professional methodological functions and activities using various teaching methods and technologies (game method, projects, trainings, interactive methods, including brainstorming, group work, taking and changing position, discussion, etc.).

\section{COMPETENCE STRUCTURE IN THE FIELD OF EDUCATION FOR SUSTAINABLE DEVELOPMENT}

On the basis of conceptual principles of the New Ukrainian School approved by the Ministry of Education and Science of Ukraine (2016), the key competencies of primary school students have been described from the perspective of sustainable development. The results of this work are presented in Table 1. 
Table 1

Characteristics of the competencies of the New Ukrainian School from the perspective of sustainable development

\begin{tabular}{|c|c|}
\hline Competency & Interpretation from the perspective of sustainable development \\
\hline $\begin{array}{l}\text { Communication in } \\
\text { Ukrainian (and also } \\
\text { in the native language } \\
\text { if it differs) }\end{array}$ & $\begin{array}{l}\text { Awareness of the impact of effective communication when ad- } \\
\text { dressing global goals of sustainable development. Ability to ex- } \\
\text { press one's position and defend it in the interests of sustainable } \\
\text { development of society. }\end{array}$ \\
\hline $\begin{array}{l}\text { Communication in } \\
\text { foreign languages }\end{array}$ & $\begin{array}{l}\text { The ability to properly understand a foreign language, to express } \\
\text { and interpret concepts, thoughts, feelings, facts and views orally } \\
\text { and in the written form, because the strategy of sustainable devel- } \\
\text { opment is international and requires intercultural communication. }\end{array}$ \\
\hline $\begin{array}{l}\text { Ability to learn } \\
\text { lifelong }\end{array}$ & $\begin{array}{l}\text { Ability to search for and learn new knowledge about sustainable } \\
\text { development of society, acquisition of new skills focused on sus- } \\
\text { tainable development, organisation of the educational process } \\
\text { through the ability to define sustainable development goals and } \\
\text { ways to achieve them, organise one's behaviour, evaluate one's } \\
\text { own learning outcomes, learn lifelong. }\end{array}$ \\
\hline $\begin{array}{l}\text { Main competencies } \\
\text { in natural sciences } \\
\text { and technologies }\end{array}$ & $\begin{array}{l}\text { Scientific approach to understanding nature and modern technol- } \\
\text { ogies, as well as the ability to apply it in the interests of sustainable } \\
\text { development. Ability to apply the scientific method, observe, for- } \\
\text { mulate hypotheses, collect data, conduct experiments, analyse the } \\
\text { obtained results related to sustainable development. }\end{array}$ \\
\hline
\end{tabular}

Ability to generate new ideas and initiatives, implement them in

Initiative and entrepreneur abilities

Social and civil competency

Environmental literacy and healthy lifestyle

\section{Mathematical competency}

Information digital competency

Culture awareness and ability to selfexpress order to improve one's own social status and well-being on the basis of sustainable development. Ability to behave rationally as a consumer, effectively use individual savings, make appropriate decisions in the field of employment, finance and others.

Patterns of behaviour necessary for effective and constructive participation in public life, in family and at work. Ability to work with others in order to achieve results, to prevent and resolve conflicts, to reach compromises. Respect for the law, respect for human rights and support for socio-cultural diversity in the interests of sustainable development.

Ability to use natural resources wisely and rationally in the framework of sustainable development. Awareness of the role of the environment for human life and health, ability and desire to follow a healthy lifestyle.

Culture of logical and algorithmic thinking. Ability to apply mathematical methods to solve certain problems in environmental, economic and social spheres of activity. Ability to build up basic mathematical models for solving problems of sustainable development. Use of information and communication technologies (ICT) for creation, retrieval, processing, and exchange of information in the interests of sustainable development. Information and media literacy, basics of programming, algorithmic thinking, working with databases, Internet security and cybersecurity skills.

Profound understanding of one's own national identity as a basis for open attitude and respect for the diversity of other people's cultural expressions for the sake of partnership for sustainable development.

Source: own research. 
It can be clearly seen that the ideas of sustainable development are harmoniously integrated into the structure of competencies that determine the theoretical and methodological content of modern Ukrainian education. However, this approach has not been reflected in real practice yet.

In the scientific literature, we find other approaches to the classification of competencies in the field of sustainable development (Glasser \& Hirsch, 2016; Steffen et al., 2015; Wiek et al., 2011). We agree with the opinion of scientists that competencies in the field of sustainable development are complexly structured because they relate to several areas of sustainability simultaneously (Kioupi \& Voulvoulis, 2019; Rauch \& Steiner, 2013).

Scientific research has allowed us to determine the structure of the key competencies in the field of sustainable development. They include not only cognitive components, but also the ability to understand the development of and the relationships between environmental, social and economic systems, social skills, values, emotions, and so on.

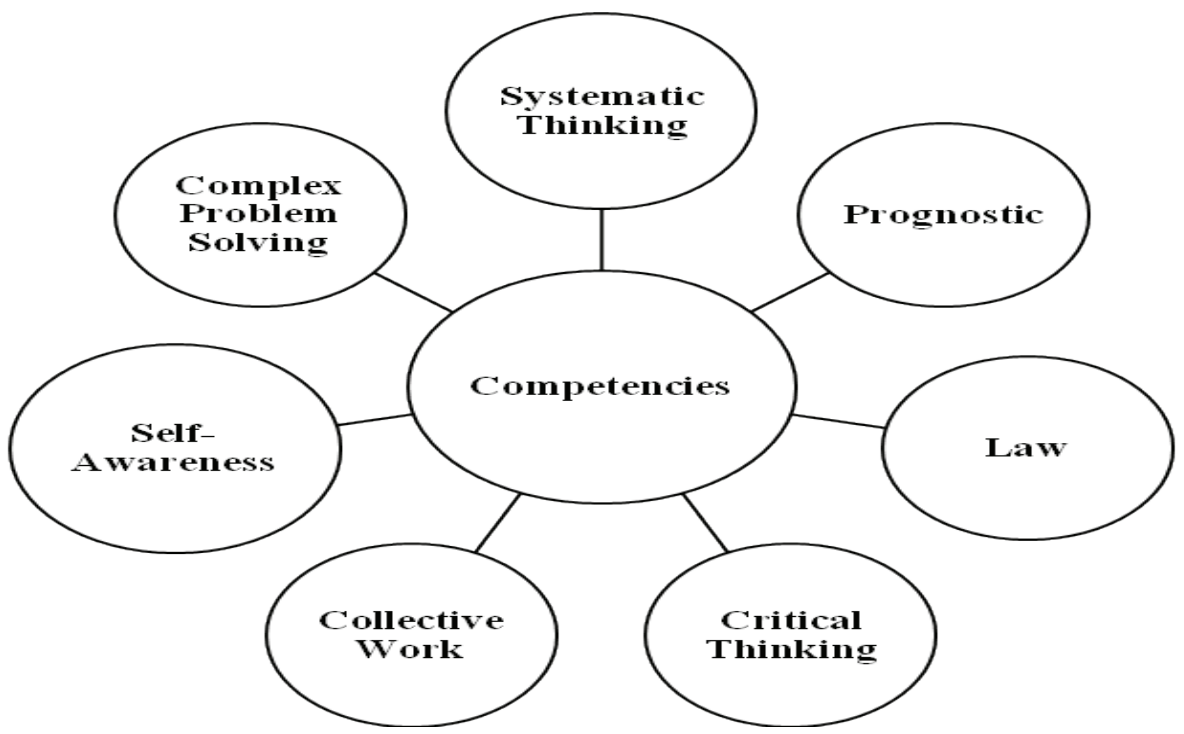

Fig. 1. The structure of competencies in the field of education for sustainable development.

Source: own research.

Systematic thinking is recognised as a key competency in the field of sustainable development (Wiek et al., 2011). According to scientists, understanding the relationship between the natural and social environment is extremely important in addressing the challenges of sustainable development (Dale \& Newman, 2005). However, a systematic thinking approach to sustainable development education is necessary not only to prepare junior students to understand the relationship between natural and social systems; it is also a 
skill attributed to the activities of a higher level of development (Rieckmann, 2012).

Prognostic (strategic) competency includes the ability to suggest different strategies or courses of action related to the challenge of sustainability. Thus, junior students need to develop the strategic knowledge necessary to motivate them to take action toward sustainable development (Grunwald, 2007).

Competency of collective work (cooperation) determines the ability to collectively develop and implement transformation strategies to change existing systems in the interests of sustainable development (Wiek et al., 2011). It includes recognising barriers, overcoming them, and anticipating the effects of change by means of effective and productive work with all the participants in the educational process. According to Wiek et al., this competency lies in the ability to "do something" in collaboration with others (2011, p. 8), as well as the child's ability to express clearly their thoughts and ideas, and apply effectively communication skills in various forms and situations. Partnership is considered to be an essential part of integrated sustainability programmes, which extends into communities and places beyond the schools (Green \& Somerville, 2015).

Law competency determines the knowledge and understanding of norms, values and beliefs in the field of sustainable development (Wiek et al., 2016).

Critical thinking determines the conduction of objective analysis and evaluation of issues in order to form a rational judgment based on evidence. In other words, it is the ability to make well-informed decisions (Steffen et al., 2015). It is also defined as the competency of thinking based on individual and social patterns of behaviour (Komasinski \& Ishimura, 2017).

Self-awareness is related to understanding personal motivation, feelings, beliefs and understanding of others. This ability allows one to perceive the world, to experience a deep emotional connection with reality and with other people.

Complex problem solving is characterised by solving difficult and clearly defined problems and the ability to use other competencies to achieve goals (Wiek et al., 2016). This is a discursive competence related to both the reception and the transmission of evaluative judgments (Glasser \& Hirsch, 2016). It defines the ability to find effective, complex and correct variants of resolution to a problem in the interests of sustainable development; it relates to responsible decision making.

\section{DIAGNOSTICS OF THE FORMATION OF SUSTAINABLE DEVELOPMENT COMPETENCIES IN PRIMARY SCHOOL STUDENTS}

The introduction of innovative approaches to solving the researched problem involves the development of corresponding diagnostic tools. It should be noted that measuring the level of formation of the key competencies is a relatively complicated task because according to our scientific research, there are no 


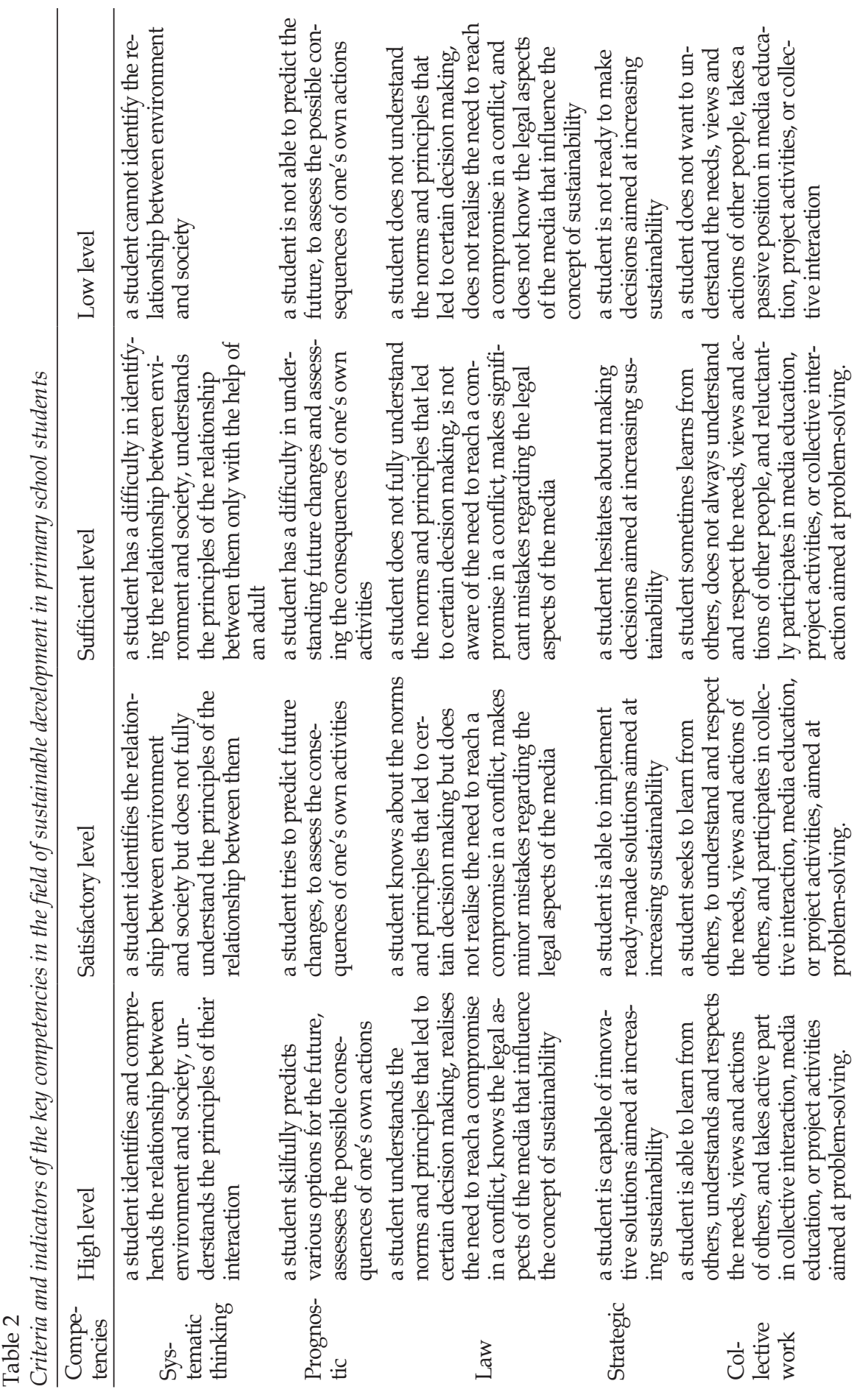


Journal of Education Culture and Society No. 2_2021 349

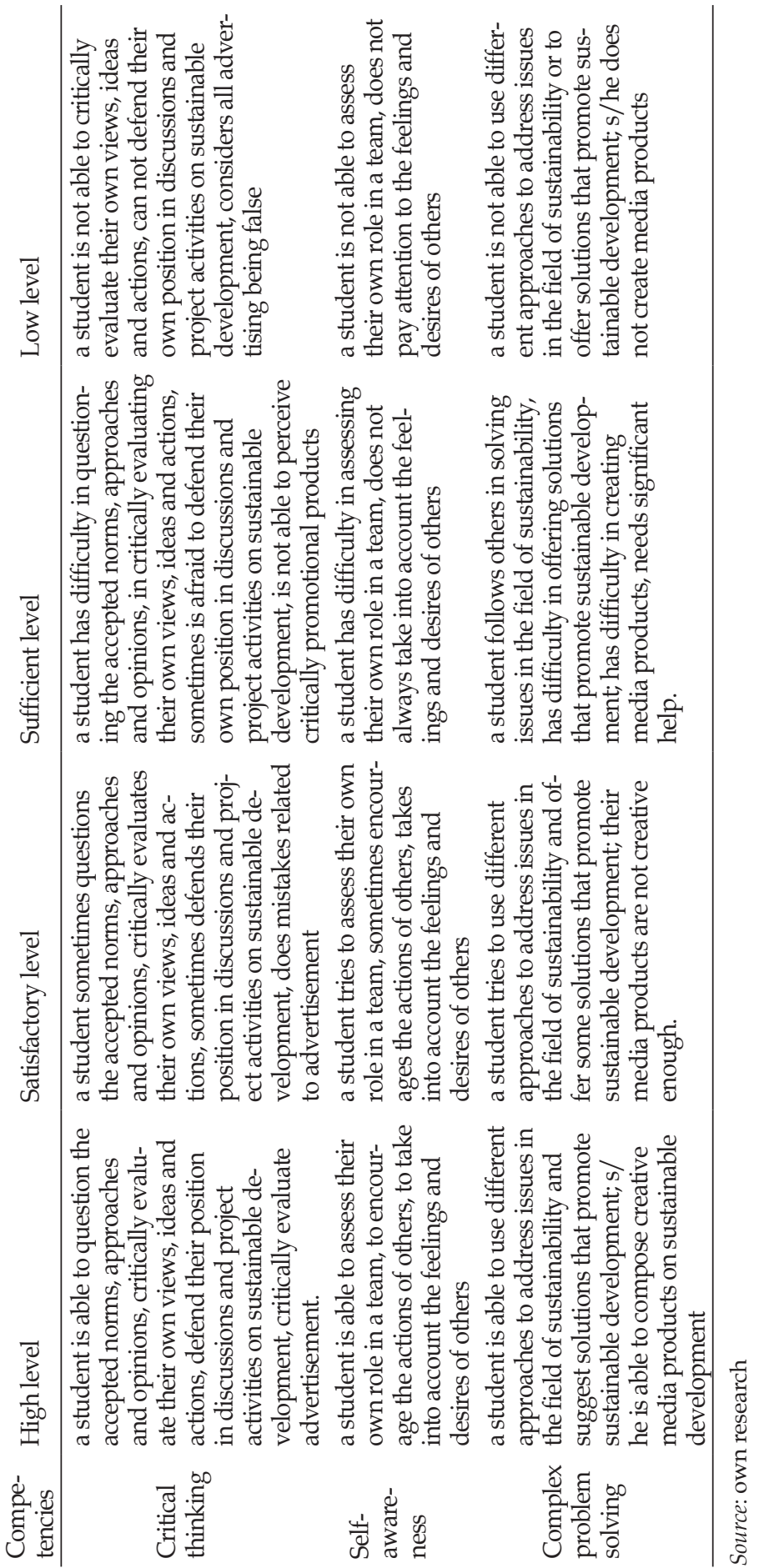


methods of their comprehensive assessment. That is why we have developed our own diagnostic criteria on the basis of the selected case studies, peculiarities of implementation and results reported in the school project "Common School Management."

The questionnaire (Appendix) was designed to make every question reflect the level of development of competencies, as defined in Table 2. The experimental survey included an empirical study on the development level of each component of the competencies in the field of education for sustainable development; it followed the criteria stated above. Furthermore, it was used for diagnosing the value of the overall level of competencies formation.

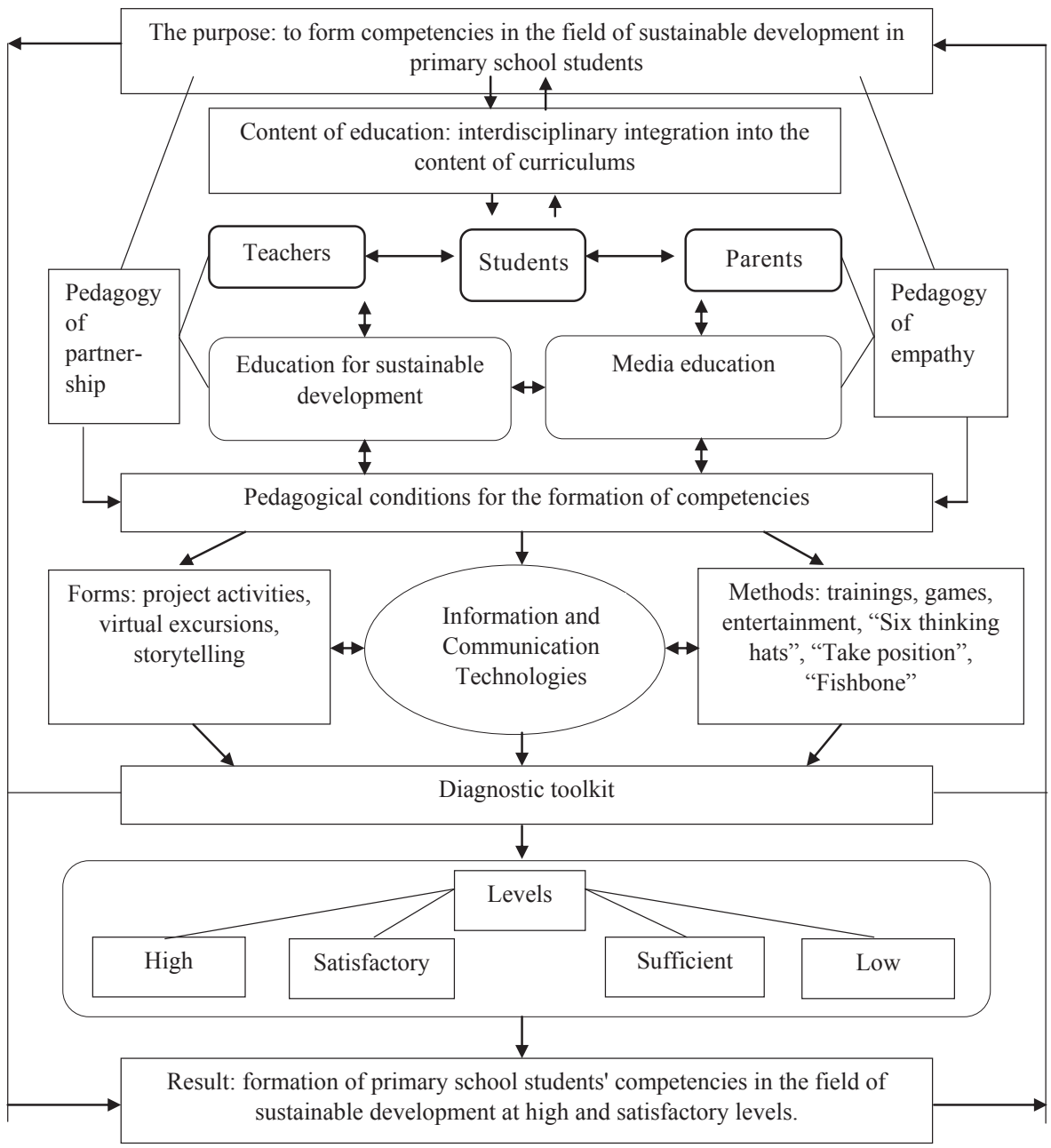

Fig. 2. Model of the methodology of formation of sustainable development competencies in primary school students.

Source: own research. 
To measure the overall level of key competencies focused on sustainable development, we identified appropriate research methods (tests, questionnaires, interviews, observations, analysis of media products, including project results) to be applied with the help of experts. The experts were teachers, parents, and school deputy principals.

The respondents' level of competencies development was measured according to the 24 point scale that implied four levels: high - from 19 to 24; satisfactory - from 13 to 18; sufficient - from 7 to 12; and, finally low - from 0 to 6 . The survey participants' total scores reflected their level of sustainable development competencies.

With help of the well-grounded diagnostic tools, the initial level of competencies in the field of education for sustainable development (pre-experiment stage) has been defined.

The number of respondents amounted to 228 students of the 4 th grade from urban and rural schools of the Ternopil region; the students were involved in all the stages of the experimental survey.

It was found that at the beginning of the experiment, the majority of students in both groups had sufficient and low levels of competency development in education for sustainable development (Table 3).

Table 3

Levels of competencies in the field of education for sustainable development: students in control and experimental groups at the beginning of the study

\begin{tabular}{lcc}
\hline \multicolumn{1}{c}{ Level of formation } & Control group & Experimental group \\
\hline \multirow{2}{*}{ High } & 19 students & 17 students \\
& $16.96 \%$ & $14.65 \%$ \\
Satisfactory & 28 students & 34 students \\
\multirow{2}{*}{ Sufficient } & $25 \%$ & $29.31 \%$ \\
& 42 students & 37 students \\
Low & $37.5 \%$ & $31.9 \%$ \\
& 23 students & 28 students \\
\hline
\end{tabular}

Source: own research.

Quantitative and qualitative analyses of the results of observation at the pre-experiment stage of the research proved that a significant number of junior students needed to complete a course, based on the methodological model designed by authors with the purpose of formation of behavioural patterns, skills and lifestyles focused on sustainable development.

The detailed analysis of scientific sources, together with our own research, have evidenced that the formation of competencies of sustainable development in primary school students demands new methodological approaches to its implementation. One of the necessary conditions is the development and employment of experimental methodology and its model. 
Methods of forming skills and competencies of students are considered to be open systems in which there are target, content, procedural and performance components. The distinctive feature of our methodology is involvement of pedagogy of partnership and pedagogy of empowerment as a methodological basis that has been identified in previous studies of pedagogical conditions of the phenomenon, and in the integration of education for sustainable development with media education (the model of methodology is shown in Figure 2).

Media education and education for sustainable development have a number of common features, primarily based on critical thinking; they are characterised by common areas of implementation (economic sphere, civil law, education of values, creation of media products). For example, the education of moral values involves the formation of high aesthetic standards in students, moral responsibility for their own actions and the actions of others. In process of creating media products (fairy tales, stories, projects, class newspapers), the ideas of sustainability are being promoted, together with useful tips on how to ensure sustainable development in economic terms (advertisement of quality media products) and others.

The content component of the methodology states that "the key role in achieving the goals of education for sustainable development is assigned to natural, civil and historical, social and health education areas," which are implemented in the primary school integrated course "I Explore the World" (Savchenko, 2021, pp.37-38). This integration, in our opinion, reflects the ideas and principles of sustainable development and competently combines its key components (Chaikovska, 2020).

In the previous studies, we identified the pedagogical conditions for achieving the goals of education for sustainable development, which are implemented with help of the course "I Explore the World" in primary school. These conditions are: updating the content of standard educational programmes for primary school with the content for sustainable development and education for sustainable development; application of the key principles of education for sustainable development in lessons and extracurricular activities; formation of soft skills in junior schoolchildren as a basis for students to make the right decisions; ensuring the interactivity of the educational environment through the use of information and communication technologies and innovative teaching methods (Chaikovska, 2021). We believe that these pedagogical conditions are interconnected and complementary, as they form a viable system of requirements necessary for the implementation of sustainable development ideas in the content of the primary school curriculum, contributing to the formation of a high level of competencies in education for sustainable development.

An important component of the experimental model is a set of diagnostic tools that contributed to the correlation analysis of the result of methodology application. 


\section{ORGANISATION OF RESEARCH AND EXPERIMENTAL WORK}

The total number of participants of the experiment equalled 228 4th-grade students. The two groups of respondents took part in the experiment aiming to implement the developed methodology and its model: 112 students in the control group and 116 students in the experimental group. In the control group, training was carried out in accordance with the standard curriculum, and in the experimental group - in accordance with the developed experimental methodology.

The necessary pedagogical conditions, forms, methods and technologies were applied in the course of study in experimental groups.

During the experimental study, the following tasks have been performed: acquainting primary school students with the concept of sustainable development as a key strategy for the resolution of global problems of mankind (carried out by modifying the content of the educational programme with the content for sustainable development and education for sustainable development); developing in children of primary school age the responsibility for their own actions and behaviour (using the principle of pedagogy of empowerment); forming practical skills of sustainable development in junior schoolchildren (implemented on the basis of formation of soft skills in junior schoolchildren); raising awareness of the importance of supporting sustainable development by each member of society (implemented through the use of interactive teaching methods and modern ICT).

Modifying the content of the educational programme with the content of sustainable development and education for sustainable development involved the integration of ideas of the education for sustainable development into the content of the integrated course "I explore the world." The experimental methodology covered the content of the most important topics: water, energy, garbage, health, relationships, plants, shopping, safe house, etc. It offered the design of lessons, practical tasks, experiments, educational extracurricular activities, etc.

Along with the consideration of sustainable development issues while teaching the integrated course "I explore the world," the experiment implemented a school project. Students from the experimental group became active participants in the school assignment "Common School Management." The purpose of the project was to incite the active participation of student government in the rational use of school resources. The project included the following activities: cleaning up the school territory and sorting garbage, optimising energy consumption, collecting waste paper, using the nearby school territory to promote the protection of rare species of flora, etc.

The principle of pedagogy of empowerment (motivation and inspiration for action) was applied using the influence on the motivational sphere of junior students in the interests of sustainable development. For this purpose, the following forms of work were used: thematic motivational games, life observations, exercises with pictures, individual research projects 
"Services and Facilities Used by My Family," watching and discussing multimedia content. Additional pieces of training - "Learning to Be Active," "Motivation of Personal Growth" were organised. Work with younger students at this stage was aimed at encouraging them to participate in research activities.

Formation of soft skills in younger students involved forming their social intelligence. In this process, such forms of work were used as debates, disputes, or business games, which motivated younger students to take active life position and initiative relatively sustainability. Pieces of training such as "Personal Qualities of a Member of Society," or "Problems of Social Communication" also contributed to the development of soft skills.

The use of interactive teaching methods and modern ICT was aimed at fostering the children's understanding of the importance of supporting sustainable development by each member of society in the process of learning. Emphasis was placed on the decisions of younger students regarding their own behaviour and lifestyle.

The most common interactive methods in the lessons were situational modelling (role play, simulation game), collective group learning (microphone, brainstorming, learning to learn, incomplete sentence, decision tree), cooperative learning (group work, pair work, aquarium, range of ideas), and elaborating discussion questions (taking position, changing position, discussion). A special place in the experimental method was occupied by the methods of critical thinking: Fishbone, which solved the problems of environmental pollution on the basis of cause-and-effect relationships; Edward de Bono's methods "Thinking Hats" (comprehensive consideration of sustainable development) and "Six Action Shoes" (each pair of shoes involves different actions in the environment and socio-economic conditions), etc. Significant attention was paid to the project activities "How to Make My City Healthier," "Give New Life to Old Things," etc. In the process of integrating education for sustainable development and media education, class newspapers with useful tips and other media products were created.

Involvement of a partnership of parents, teachers and students was considered to be a significant method, it resulted in meaningful activities such as storytelling after a virtual tour (e.g. a virtual tour to the Chernobyl zone). Causal links between the use of electricity at home, its economic consumption and the development of nuclear energy were established and the possible consequences for mistakes were discussed. Children were inspired to compose both prose works and verse lines: "I went to Chernobyl with my parents... And I got into a completely different world... There a new life has already blossomed, but something else is destroyed forever."

At the end of the experiment, diagnostic procedures were performed again. The analysis of the results of the post-experiment inventory showed positive dynamics in the formation of competencies in the field of education for sustainable development in the experimental group (Table 4). 
Table 4

The level of competencies formation in the field of education for sustainable development of students in the control and experimental groups at the end of the study

\begin{tabular}{lcc}
\hline \multicolumn{1}{c}{ Levels } & Control group & Experimental group \\
\hline High & 21 students & 31 students \\
& $19 \%$ & $26.72 \%$ \\
Satisfactory & 27 students & 51 students \\
& $24 \%$ & $43.96 \%$ \\
Sufficient & 44 students & 22 students \\
& $39 \%$ & $18.97 \%$ \\
Low & 20 students & 12 students \\
& $18 \%$ & $10.35 \%$ \\
\hline
\end{tabular}

Source: own research.

Comparative results are presented in Figure 3. At the beginning of the experiment, the number of respondents in the experimental group with a high level of special competencies was $14.65 \%$, while at the end of the experiment - $26.72 \%$. The number of students with a low level of competencies decreased from $24.14 \%$ to $10.35 \%$ (Table 4 ).

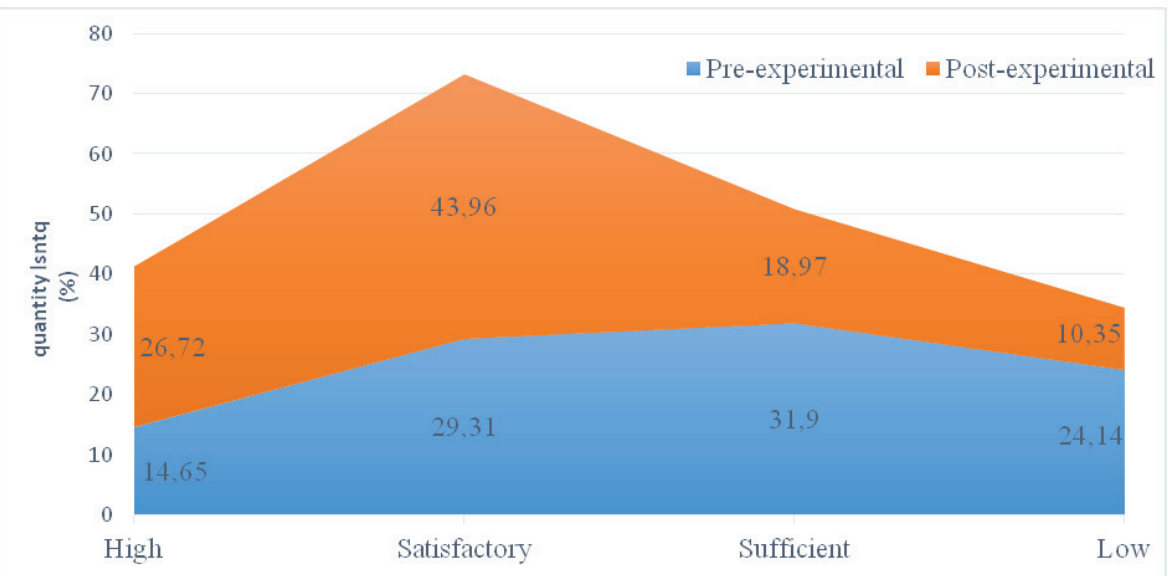

Fig. 3. Dynamics of the formation of competencies in the field of sustainable development in students of the experimental group.

Source: own research.

Eventually, there were some changes in the level of formation of competencies in the field of education for sustainable development in the control group (Table 4). However, these changes are less significant. Thus, the analysis of the dynamics of the formation of competencies of junior schoolchildren in the field of education for sustainable development testifies to the effectiveness of the introduced pedagogical conditions for its formation. 


\section{DISCUSSION}

The analysis of the conducted work testifies to the necessity of carrying out systematic work, substantiation of new methods for resolution of the problems of forming competencies in the field of sustainable development in primary school students.

We consider compliance with the principles of empowerment pedagogy and partnership pedagogy to be the key element of the model. They provide respect for the child's personality and its support, stimulating child's activity with questions, not answers, involving all children in the learning process with emphasis on the importance of everyone's participation; promoting the construction of classes on the basis of communicativeness, productive and tolerant cooperation, and teacher's trust in a child's potential, which is expressed in giving a child an opportunity to choose the mode of action, the necessary means and time for its implementation, while avoiding competition, negative evaluation, pressure on the child (Pometun, 2015).

In our study, we saw that the implementation of the principles of empowerment pedagogy in the educational process helps to ensure the relationship between the values and behaviour of primary school students; the activity of the subject and motivation to work for sustainable development; and unity of the content of the goals of sustainable development with the daily life of primary school students. We agree with the opinion that the development of internal motives is the key to the development of integrated competencies (Matvieieva, Ovcharenko, Korchagina, Kuznetsova, \& Grineva, 2019).

At the same time, the idea of combining media education and education for sustainable development is new and needs new methodological developments.

\section{LIMITATIONS}

The generalisability of the obtained results might be subject to certain limitations. The geo-spatial coverage was restricted to only one region in Western Ukraine: only the residents of the Ternopil region took part in the experiment. However, a large number of participants (228 people) being representatives of both rural and urban schools is a factor ensuring the reliability of study results.

\section{CONCLUSION}

The formation of competencies in the field of sustainable development in primary school students is an urgent problem that requires the introduction of new approaches to its solution. One of them is the method of forming the studied phenomenon, the peculiarity of which lies the introduction of partnership and empowerment pedagogy, integration of sustainable development education with media education, compliance with a number of pedagogical conditions, forms and methods, among which there are virtual tours combi- 
ned with storytelling, games, entertainment, interactive methods, methods of critical thinking by Edward de Bono's "Thinking Hats," "Six Action Shoes," as well as the Fishbone method, project activities, pieces of training and others.

The verification of the experimental model in the space of primary education on the formation of competencies in the field of sustainable development in junior schoolchildren proved its effectiveness. At the ascertaining stage of the experiment, the number of respondents in the experimental group with a high level of researched competencies was $14.65 \%$; at the end of the experiment, it was $26.72 \%$. Furthermore, the number of students displaying a satisfactory level of competencies formation increased from $29.31 \%$ to $43.96 \%$; the number of students who showed an sufficient level decreased from $31.9 \%$ to $18.97 \%$, and low - also decreased from $24.14 \%$ to $10.35 \%$. In our opinion, the conducted work contributed to the fact that the participants of the formative experiment not only became the subjects of educational and developmental influences but also the subjects of self-knowledge, self-development and personal self-realisation.

However, this research does not cover all aspects of formation of sustainable development competencies in primary school students. We see the prospects for further research regarding the improvement of forms, methods and means of formation of the key competencies in junior high school students in the field of sustainable development. It is considered necessary to further explore the role of project activities in the process of formation of the key competencies in the field of sustainable development, as this learning technology affects the development of all its components and is of interest to younger students.

The results of the study will contribute to the growth of the key competencies in the field of education for sustainable development in younger students. They can be used in modification of curriculums, in writing guidelines and manuals, also in practice.

\section{REFERENCES}

[1] Benavot, A. (2014). Education for sustainable development in primary and secondary education. University at Albany-State University of New York. doi:10.13140/RG.2.1.1978.9283

[2] Carm, E. (2013). Rethinking education for all. Sustainability, 5(8), 3447-3472.

[3] Chaikovska, Н. В. (2020). Професійна підготовка майбутніх учителів початкової школи на засадах сталого розвитку. [Professional training of future primary school teachers on the basis of sustainable development]. Scientific Bulletin of Uzhhorod University. Series: "Pedagogy. Social Work», 1(46), 138-142.

[4] Chaikovska, Н. В. (2021). Освіта для сталого розвитку в сучасній початковій школі: умови впровадження. [Education for sustainable development: Conditions of introduction], Pedagogical Almanac, 47, 50-58.

[5] Dale, A., \& Newman, L. (2005). Sustainable development, education and literacy. International Journal of Sustainability in Higher Education, 6(4), 351-362.

[6] Glasser, H., \& Hirsch, J. (2016). Toward the development of robust learning for sustainability core competencies. Sustainability, 9(3), 121-134. doi:10.1089/sus.2016.29054.hg.

[7] Green, M., \& Somerville, M. (2015). Sustainability education: Researching practice in primary schools. Environmental Education Research, 21(6), 832-845. doi:10.1080/13504622.2014.923382.

[8] Grunwald, A. (2007) Working towards sustainable development in the face of uncertainty 
and incomplete knowledge. Journal of Environmental Policy and Planning, 9(3), 245-262.

[9] Kioupi V., \& Voulvoulis N. (2019). Education for sustainable development: A systemic framework for connecting the SDGs to educational outcomes. Sustainability, 11(21), 6104. doi:10.3390/su11216104.

[10] Komasinski, A., \& Ishimura, G. (2017). Critical thinking and normative competencies for sustainability science education. Journal of Higher Education and Lifelong Learning, 24, 21-37.

[11] Matvieieva, O., Ovcharenko, N., Korchagina, A., Kuznetsova, O., \& Grineva, V. (2019). Study of aspects facilitating "lifelong learning" competence development in high school students. Revista Romaneasca pentru Educatie Multidimensionala, 11(2), 180-197. doi:10.18662/rrem/124.

[12] Ministry of Education and Science of Ukraine (2016). The New Ukrainian School. Conceptual principles of secondary school reform. Retrieved from https://mon.gov.ua/storage/app/ media/zagalna\%20serednya/Book-ENG.pdf.

[13] Munkebye, E., Scheie, E., Gabrielsen, A., Jordet, A. N. N., Misund, S., Nergård, T., \& Øyehaug, A. B. (2020) Interdisciplinary primary school curriculum units for sustainable development. Environmental Education Research, 26(6), 795-811. doi:10.1080/13504622.2020.1750568

[14] Pometun, O. I. (2015). Педагогічні засади освіти для сталого розвитку в Українській школі. [Pedagogical foundations for sustainable development in Ukrainian school]. Ukrainian Pedagogical Journal, 1, 171-182.

[15] Rauch, F., \& Steiner, R. (2013). Competences for education for sustainable development in teacher education. Center for Educational Policy Studies Journal, 3(1), 9-24.

[16] Rieckmann, M. (2012). Future-oriented higher education: Which key competencies should be fostered through university teaching and learning? Futures, 44(2), 127-135.

[17] Summers, M., \& Kruger, C. (2003). Teaching sustainable development in primary schools: Theory into practice. The Curriculum Journal, 14(2), 157-180. doi:10.1080/09585170302836.

[18] Savchenko, O. Yа. (2021). Типова освітня програма [A typical curriculum]. Retrieved April 18, 2021 from https://mon.gov.ua/storage/app/media/zagalna\%20serednya/programy-1-4-klas/2019/11/1-2-dodatki.pdf.

[19] da Silva, A. W. P., Coelho, A. L. D. A. L., dos Santos, H. C. C., Neto, A. R. V., de Castro, A. B. C., \& El-Aouar, W. A. (2020). Education principles and practices turned to sustainability in primary school. Environment, Development and Sustainability, 22(7), 6645-6670.

[20] Steffen, W., Richardson, K., Rockström, J., Cornell, S. E., Fetzer, I., Bennett, E. M., Biggs, R., Carpenter, S. R., De Vries, W., De Wit, C. A., et al. (2015). Planetary boundaries: Guiding human development on a changing planet. Science, 347(6223), 1259855. doi:10.1126/science.1259855.

[21] Szadzińska, E. (2017). Zrównoważony rozwój inspiracją dla zmian w edukacji wczesnoszkolnej. [Sustainable development as an inspiration for changes in high school education.]. Lubelski Rocznik Pedagogiczny, 36(1), 29-40.

[22] Tkáčová, H., Pavlíková, M., Tvrdoň, M., \& Jenisová, Z. (2021). The use of media in the field of individual responsibility for sustainable development in schools: A proposal for an approach to learning about sustainable development. Sustainability, 13(8), 4138. doi:10.3390/su13084138.

[23] UNESCO (2021). Transforming our world: The 2030 agenda for sustainable development. Retrieved May 12, 2021 from https://www.un.org/ga/search/view_doc.asp?symbol=A/ RES/70/1\&Lang=E.

[24] Vásquez, C., García-Alonso, I., Seckel M. J., \& Alsina Á. (2021). Education for sustainable development in primary education textbooks - An educational approach from statistical and probabilistic literacy. Sustainability, 13(6), 3115. doi:10.3390/su13063115.

[25] Wiek, A., Bernstein, M., Foley, R., Cohen, M., Forrest, N., Kuzdas, C., Kay, B., \& Withycombe Keeler, L. (2016). Operationalizing competencies in higher education for sustainable development. In M. Barth, G. Michelsen, M. Rieckmann \& I. Thomas (Eds.) Routledge handbook of higher education for sustainable development (pp. 241-260). London and New York: Routledge.

[26] Wiek, A., Withycombe, L., \& Redman, C. L. (2011). Key competencies in sustainability: A reference framework for academic program development. Sustainability Science, 6(2), 203-218. doi:10.1007/s11625-011-0132-6. 


\section{APPENDIX}

\section{Questionnaire}

This appendix consists of the questionnaire that has been applied in the study at the stage of the experimental survey. It was developed on the basis of the selected case studies, peculiarities of implementation and reported results of the school project "Common School Management." The questionnaire was designed to make every question address the level of development of one of the competences in the field of education for sustainable development.

1. While cleaning up the apartment, you found your old child picture books. Now you are no longer interested in them. What will you do?

a) I will give it to younger children and thus save trees and clean air.

b) I will bring it to the waste paper collection centre.

c) I will keep it in a garage or attic, may still come in handy.

d) I will throw it in the garbage bin.

2. Will the environment change if we constantly throw things we don't need in the trash and buy new ones?

a) Yes, the production of new goods requires raw materials that man takes from nature, violating its integrity.

b) It will change due to the fact that the number of people increases and their needs increase.

c) It will not change very much; nature is capable of recovery.

d) It will not change, people learnt to recycle waste.

3. If your friend has a different opinion about garbage sorting than you do, you will:
a) talk and together you find the right solution.
b) insist on your own, because it is correct.
c) ask an adult for help in resolving the dispute.
d) not enter into a dispute.

4. What can you do with old things?
a) Use them in interesting volunteer projects.
b) Give them to the Red Cross.
c) Throw them in the trash.
d) I don't know, I never cared about that.

5. The students in your class decided to collect wasted paper. What is your role in this?
a) I know how to make such an event more effective.
b) I certainly join the event and make my contribution.
c) I may join if I will have the opportunity.
d) I'm not interested, I am busy.

6. Your friend thinks there is no need to sort trash. What do you think?
a) I am convinced that garbage sorting is economically and environmentally beneficial.
b) I believe that sorting and recycling will save the environment. 
c) I partially agree because the construction of waste processing plants requires large resources.

d) I completely agree; it is not economically viable.

7. The teacher suggested making a classroom library and asked the students to bring books they had read to share with others. What will you do?

a) I will help the teacher in organising this great idea and tell classmates how cool it is.

b) I will bring books I have already read to school.

c) If I am asked to join, I will take part.

d) I do not like to read and I don't think it is an interesting idea.

8. When the class discusses world events and global issues, you:
a) always try to express your opinion on solving these issues.
b) sometimes you can offer your vision of these problems.
c) listen carefully to the teacher and my classmates.
d) are not always interested in these topics. 